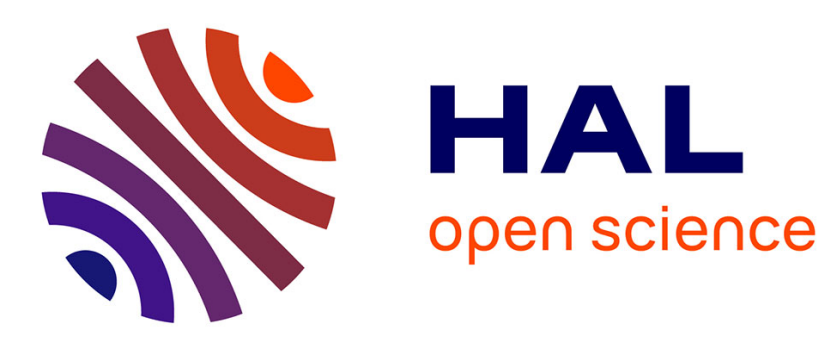

\title{
Migration and Institutions: Exit and Voice (from Abroad)?
}

Thierry Baudassé, Rémi Bazillier, Ismaël Issifou

\section{To cite this version:}

Thierry Baudassé, Rémi Bazillier, Ismaël Issifou. Migration and Institutions: Exit and Voice (from Abroad)?. 2016. hal-02484265

\section{HAL Id: hal-02484265 \\ https://hal.science/hal-02484265}

Preprint submitted on 19 Feb 2020

HAL is a multi-disciplinary open access archive for the deposit and dissemination of scientific research documents, whether they are published or not. The documents may come from teaching and research institutions in France or abroad, or from public or private research centers.
L'archive ouverte pluridisciplinaire HAL, est destinée au dépôt et à la diffusion de documents scientifiques de niveau recherche, publiés ou non, émanant des établissements d'enseignement et de recherche français ou étrangers, des laboratoires publics ou privés. 
Document de Recherche du Laboratoire d'Économie d'Orléans DR LEO 2016-20

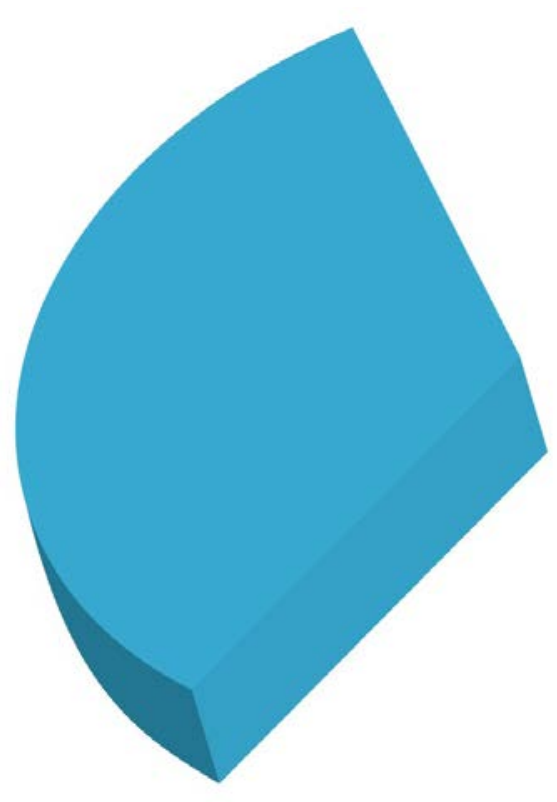

Migration and Institutions: Exit and Voice

(from Abroad)?

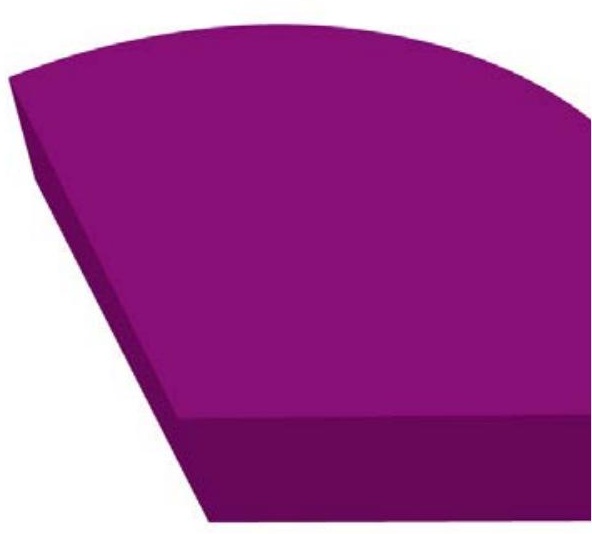

Thierry BAUDASSÉ

Rémi BAZILLIER

Ismaël ISSIFOU

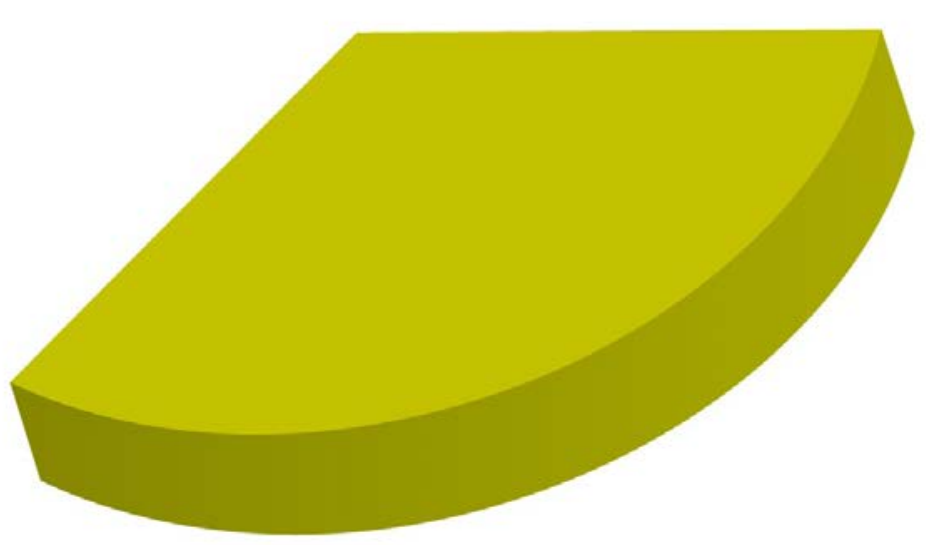




\title{
Migration and Institutions: Exit and Voice (from Abroad)?
}

\author{
Thierry Baudassé, Rémi Bazillier, Ismaël Issifou \\ ${ }^{a}$ Univ.Orléans, CNRS, LEO, UMR7322, F45067, Orléans, France \\ ${ }^{b}$ Univ.Orléans, CNRS, LEO, UMR7322, F45067, Orléans, France \\ ${ }^{c}$ Université Paris 1 Panthon-Sorbonne, CES, UMR CNRS 8174, France
}

\begin{abstract}
A rapidly growing body of research examines the relationship between migration and institutions. Three strands of studies can be distinguished. Some studies focused on the role of domestic and foreign institutions in the decision to migrate. Others were interested by the impact of migration on institutional reforms in migrants' countries of origin. While the effect of migration on destination countries is largely documented, recent studies focus on how migrants affect social and informal institutions in the destination countries. This survey puts together these three strands of literature with three purposes. First, we offer a short definition and synthetic typology of institutions, which provide a guide to understand several studies summarized and their results. Second, our analysis is presented following the analytic framework exit,voice and loyalty of Hirschman in order to highlight the brain grain phenomenon for developing countries, from an institutional point of view. Third, we review the limited existing work on the very timely topic, whether migrants are harmful or not to institutions in the host countries.
\end{abstract}

Keywords: Institutions, Migration.

\section{Introduction}

The anti-government protests that began in Syria in early 2011 were seen as a continuation of the Arab Spring uprising against autocratic regimes. In the exit, voice and loyalty analytic framework of Hirschman (1970), the fact that people express their dissatisfaction through general protest is consistent with the voice option. The alternative is the exit option which represents the choice of leaving the country. If early studies in economics were quite interested in economic and demographic factors as key pull and push factors explaining why people move, recent research has depicted migration as a more complex phenomenon which requires political, social and cultural variables to be better understood (Clemens et al., 2014).

In this respect, institutions become one of the key determinants of international migration, often treated as both a push and a pull factor. On the one hand, the poor performance of institutions may be a sufficient motive for leaving a home country in search of institutions which perform better abroad. ${ }^{1}$ On the other hand, the quality of institutions may determine the destination country that candidate migrants will choose. Several studies give 
theoretical and empirical support to the role played by different types of institutions in the decision to migrate ranging from economic (rule of law, property rights), political (civil rights, democracy) to social institutions (gender inequality, social protection).

The fact that the choice to migrate can be shaped by the quality of institutions in the home country raises another key strand of the literature: the loss of those fighting for better institutions. In the exit and voice dichotomy of Hirschman (1970), those discontented with institutions in their origin country who exit (leave) simply waive any attempt to change them. Therefore, the push factor characteristic of institutions is detrimental by worsening the already low quality of institutions in the sending countries. However, it is important to note that the human capital loss recorded by certain countries due to emigration relates only to migrants who no longer maintain any connection to their origin countries. And one can imagine that this is not the case for some migrants still concerned with the political, economical and social situations in their origin country. Indeed, many migrants form diasporas which are very active in the development process of their origin country. To assess the participation of migrants from abroad, Barry (1974) extends the analytic framework of Hirschman (1970). Barry (1974) opposes voice to silence and argues that these two mutually exclusive options are possible both when staying at home and when going abroad. This implies that unlike Hirschman (1970), the decision to stay at home is not a guarantee that those who stay will voice. They can remain silent if they feel unable to react to bad institutional choices. Likewise, emigrating does not inherently imply remaining silent as diaspora members with ideological and philanthropic considerations may take part to actions aiming at significantly enhancing the quality of institutions in their origin country. This transforms the mutually exclusive exit or voice options proposed by Hirschman (1970) into complementary options.

In this respect, the participation of migrants to the development process in their origin country receives much attention in the literature. If the role played by migrants in their origin country is recognized, only certain aspects dominate the literature. For instance, the economic contribution of migrants (more often by way of remittances) is largely examined while their institutional impact is less investigated. Yet historically, migrants' actions in numerous causes such as the decolonization process and the independence of their nation are recognized. Their role was also instrumental against discrimination or segregation like the apartheid in South Africa.

Whether the development activities of migrants are oriented towards economic, social or political change in the origin country, depends on their competences. According to Chukwu-Emeka (2011), the involvement of migrants in specific development areas is shaped by their financial, intellectual, political, cultural or social capital. Those migrants' skills broadly gained in the destination country vary from one migrant to another and may guide the engagement of migrants. The little attention given to the role played by migrants in the development of their home country institutions is partly explained by the fact that institutions change slowly and it may seem difficult to conceive that a handful of individuals from abroad can change them. There are also difficulties in identifying channels through which migrants contribute to the development of their origin country other than the economic ones, by way of remittances. For this reason, a clear theory stating how migrants are going 
to affect the institutions in their origin country is needed. Moreover, it can also be argued that the political actions of migrants are context-specific so that they represent the exception rather than the rule.

The goal of this survey is to analyze the two way relationship between institutions and migration. The focus on the fact that migration is caused by, and in turn impacts, the quality of institutions will distinguish this survey from the literature on the determinants of migration on the one hand and the broadly development role attributed to migration in the origin countries on the other. We will review the impact of institutions both in the origin and in the destination countries on the choice of migrating and settling in a given destination country. Next, we will examine the impact of migrants on both their home country institutions and the destination country institutions. An analysis of what institutions are and a presentation of the various typologies of institutions in the literature is proposed first. We will also offer a crosstab with different typologies that will help to distinguish between economic, social and political institutions that may influence the decision to migrate and that migration in turn may impact.

This survey is organized as follows. Section 2 is devoted to the definition and the typologies of institutions. In section 3, we analyze institutions as a push factor as well as a pull factor of international migration. In section 4 , the institutional change made by migrants in their origin country and the channels through which their actions work are investigated. We also briefly discuss the effect of migrants on the institutions in the destination country. The last section concludes.

\section{What Are Institutions?}

A very large part of the economic literature discusses the relationship between institutions and migration. On the one hand, institutions appear to be an important factor in the migration process. On the other hand, migration in turn affects institutions. If "migration" is not an ambiguous term, the definition of institutions is not totally clear. As it will be discussed, the definition of institutions goes back at least to the founder of the French school of Sociology Emile Durkheim in 1894, approximately at the same time that the "Institutionalist School" was founded by the American economist and sociologist Thorstein Veblen. In spite of these relatively old definitions, at least 3 articles have been published more recently with the only concern of better defining institutions (de Pina-Cabral, 2011; Hodgson, 2006; Searle, 2005). In this section, we will first give some important definitions of institutions. Then, we will define the terms conventions, norms, rules and organizations, often evoked when defining institutions. Finally, we will discuss various typologies of institutions considering the opposition between formal and informal institutions as the starting point.

\subsection{Defining Institutions}

In the preface of the second edition to the "Rules of Sociological Method" Durkheim writes "without doing violence to the meaning of the word, one may term an institution

all the beliefs and modes of behaviour instituted by the collectivity; sociology can then be defined as the science of institutions, their genesis and their functioning" (Durkheim, 1982, p. 
45, original edition 1894). Approximately at the same period, Thorstein Veblen was defining institutions in "The Theory of Leisure Class" as the "prevalent habits of thought with respect to particular relations and particular functions of the individual and the community" (Veblen, 2007, p. 126, original edition 1899). While Veblen insists on the concept of habits of thought, Durkheim uses the concept of beliefs and mode of behavior. But, Durkheim also insists on the "external" and "coercive" aspects of the institution, which makes it a "social fact". Douglas North one of the most prominent authors of the "new institutionnalist" approach defines institutions in several ways. In North $(1984$, p. 8) institutions are defined as "a set of constraints on behavior in the forms of rules and regulations, a set of procedures to detect deviations (...) and finally a set of (...) norms (...) that constrain the way in which the rules and regulations are specified and enforcement is carried out" while North (1991, p. 97) defines them as "the humanly devised constraints that structure political, economic and social interaction".

\subsection{Typology of Institutions}

The most classical typology of institutions is the difference between "formal" and "informal" institutions. This classification appears for instance in North (1991, p. 97) who writes : "Institutions consist of both informal constraints (sanctions, taboos, custom, traditions, and codes of conduct), and formal rules (constitutions, laws, property rights)". Hodgson (2006, p. 18) discusses the accuracy of this distinction between formal and informal institutions or rules. "Does the term formal mean legal, written, explicit, codifiable, or something else? The ambiguities surrounding these terms mean that they cannot be taken for granted" (p. 18). Hodgson argues that there is no dividing line between formal and informal institutions because formal institutions always depend on inexplicit norms in order to operate. "Legal or formal institutions that do not have strong informal supports are unsupported legislative declarations rather than real institutions". In that case, legal or formal institutions are mere declarations and not effective social rules. This is the root of the distinction between rules "de jure" and "de facto". In some cases, informal institutions can be stronger than formal ones and be opposed to them; for instance gender discrimination can exist in the social norms of a country and be considered as illegal in the formal rules. As Hodgson says, "this does not mean that legal rules are unimportant but they become important by becoming incorporated in custom and habit" (Hodgson, 2006, p. 18). Poppo and Zenger (2002) also discuss the opposition between formal and informal institutions.

Vatn (2006) establishes a more original typology distinguishing between institutions which act as coordinating devices and those which regulate conflicts. "In a complex world understanding and communicating is difficult. A large list of conventions is developed to support such coordination (...). Norms, on the other hand, emphasize values. They prescribe certain acts as expected in certain situations" (p. 3). According to this vision, we can divide the institutions in another way than the usual formal/informal opposition. Coordinating devices institutions are the language, the metric system, the time convention, but also the rules of politeness, the behavioral conventions - as the one setting that the person who first placed the call is calling back if disconnected. On the other hand, the conflict regulation devices institutions are the legal system, or the traditional and informal 
rules permitting the regulation of social conflicts. We can see that this distinction and the formal/informal one are orthogonal, as it can be summarized in the following table.

Table 1: Crosstab between coordination device, regulation of conflicts, formal and informal institutions

\begin{tabular}{llc}
\hline & Coordination device & Regulation of Conflicts \\
\hline Formal & language, metric system, time convention & legal system \\
Informal & rules of politeness, behavioral conventions & traditional and informal rules \\
\hline
\end{tabular}

Williamson (2000) uses a different typology of institutions, distinguishing between four levels of social analysis, from the most general institutional context which changes very slowly to the level of resource allocation and employment (prices and quantities) which evolves continuously. The top level is called "social embeddedness level" and it includes norms, customs, mores, traditions (...). This level is very close to the concept of "social capital" broadly used in social theory - e.g. Durlauf and Fafchamps (2004). The evolution at this level occurs rarely, on the order of centuries or millennial. A second level is referred to as "institutional environment" and is constituted by the "formal rules of the game" like constitutions, laws, property rights. These formal rules change with a frequency going from decades to centuries. The third level is the "governance" level which deals with the way the contractual relations are ruled, so that to produce order and mitigate conflicts. This level is changing faster - on the order of years or decades. Finally the resource allocation is the lowest level of analysis - the one the neoclassical economics deal with and which is subject to continuous change.

Rodrik and Subramanian (2003) propose another typology of institutions. They term "market creating institutions" the ones which protect property rights and ensure that contracts are enforced. Then they distinguish "market regulating institutions" that are those which deal with externalities, economies of scale and imperfect information, "market stabilizing institutions" that are the ones which ensure low inflation, minimize macroeconomic volatility and prevent financial crisis and finally "market legitimizing institutions" namely those that provide social protection, insurance, or redistribution.

Finally, Acemoglu et al. (2005) consider that economic performances and distribution of resources are the results of economic institutions, which are themselves the result of an interaction between political institutions, distribution of resources and de jure and de facto political power, as it appears in the following graph:

In this way, these authors implicitly make a typology between political and economic institutions, which can be formal or informal according to the typology of North. ${ }^{2}$ We can add to this distinction the concept of "social institutions" which would be similar to the "market legitimizing institutions" in Rodrik and Subramanian (2003). This would lead to the following typology: 


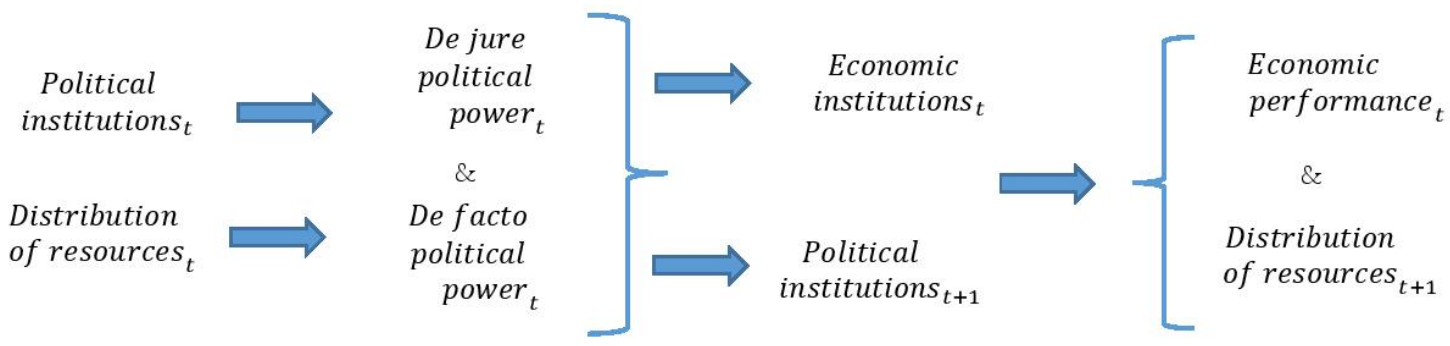

Figure 1: Reproduction of Acemoglu et al. (2005) diagram

Table 2: Crosstab between Political, Social, Economic Institutions, formal and informal institutions

\begin{tabular}{lccc}
\hline & Political Institutions & Social Institutions & Economic Institutions \\
\hline \multirow{2}{*}{ Formal } & Constitution & Social Protection & Property Rights \\
& Civil Rights & Income redistribution & Entrepreneurship \\
\multirow{2}{*}{ Informal } & Tolerance & Informal solidarity & Corruption \\
& Political participation & Volunteering & \\
\hline
\end{tabular}

Based on this typology, table (3) summarizes measures of institutions variables used by authors who studied the relationship between migration and institutions. 
Table 3: Type and different measures of institutions used in the migration-institutions literature.

\begin{tabular}{|c|c|c|c|c|}
\hline $\begin{array}{l}\text { Division } \\
\text { level } 1\end{array}$ & $\begin{array}{l}\text { Division } \\
\text { level } 2\end{array}$ & Variables & Measures & Authors \\
\hline \multirow[t]{2}{*}{$\begin{array}{l}\text { Political } \\
\text { institutions }\end{array}$} & Formal & $\begin{array}{ll}\text { Political } & \text { Con- } \\
\text { stitution, } & \text { Civil } \\
\text { Rights } & \end{array}$ & $\begin{array}{l}\text { Indexes of governance } \\
\text { including gouvern- } \\
\text { ment effectiveness, } \\
\text { regulatory quality... } \\
\text { (Worldwide Gover- } \\
\text { nance Indicators ; } \\
\text { Polity variable from } \\
\text { Polity IV ; Freedom } \\
\text { House Index) }\end{array}$ & $\begin{array}{l}\text { Bergh et al. (2015) } \\
\text { Bertocchi and Strozzi } \\
(2008)\end{array}$ \\
\hline & Informal & $\begin{array}{l}\text { Tolerance, } \\
\text { Political Partici- } \\
\text { pation, Political } \\
\text { Stability, Civil } \\
\text { Conflicts }\end{array}$ & $\begin{array}{l}\text { International Country } \\
\text { Risk Guide (ICRG) }\end{array}$ & $\begin{array}{l}\text { Dutta and Roy (2011) } \\
\text { Blattman and Miguel } \\
(2010)\end{array}$ \\
\hline \multirow[t]{2}{*}{$\begin{array}{l}\text { Social } \\
\text { institutions }\end{array}$} & Formal & $\begin{array}{l}\text { Social Protec- } \\
\text { tion, Income } \\
\text { redistribution } \\
\text { mechanisms, } \\
\text { Labor Market } \\
\text { Institutions, } \\
\text { Gender equality }\end{array}$ & $\begin{array}{l}\text { - Gender equality } \\
: \text { indexes based on } \\
\text { women's income, } \\
\text { women's literacy, } \\
\text { female labor force } \\
\text { participation and un- } \\
\text { employment, female } \\
\text { education enrollment } \\
\text {.. } \\
\text { - Social Protection } \\
\text { : aid to families, so- } \\
\text { cial public spendings, } \\
\text { unemployment bene- } \\
\text { fits ... } \\
\text { - Labour Market } \\
\text { Institutions: trade } \\
\text { union rights, employ- } \\
\text { ment protection leg- } \\
\text { islation, workers pro- } \\
\text { tected by wage agree- } \\
\text { ments, cost of firing } \\
\text { workers, cost of in- } \\
\text { creasing hours worked } \\
\ldots\end{array}$ & 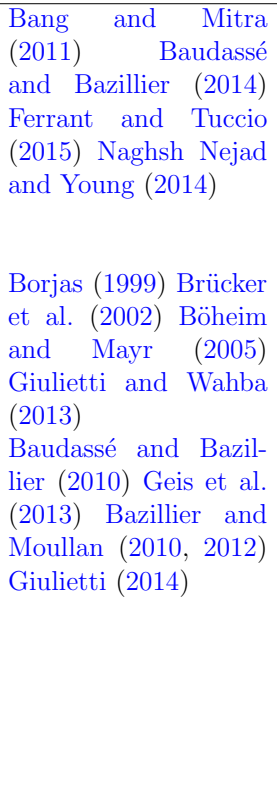 \\
\hline & Informal & $\begin{array}{lr}\text { Informal } & \text { Soli- } \\
\text { darity, } & \text { Social } \\
\text { Capital } & \text { and } \\
\text { Trust, } & \text { Family } \\
\text { structure } & \end{array}$ & $\begin{array}{l}\text { xenophobic behavior } \\
\text { fertility norms } \\
\text { Trust (World Value } \\
\text { Survey, General Social } \\
\text { Survey) }\end{array}$ & $\begin{array}{l}\text { Licuanan et al. (2015) } \\
\text { Beine and Sekkat } \\
(2013) \text { Bertoli and } \\
\text { Marchetta (2015) } \\
\text { Davis (2011) Lind- } \\
\text { strom and Saucedo } \\
(2002) \text { Putnam (2007) } \\
\text { Collier (2013) Borjas } \\
(2015)\end{array}$ \\
\hline \multirow[t]{2}{*}{$\begin{array}{l}\text { Economic } \\
\text { institutions }\end{array}$} & Formal & $\begin{array}{l}\text { Property Rights, } \\
\text { Economic Free- } \\
\text { dom, En- } \\
\text { trepreneurship }\end{array}$ & $\begin{array}{l}\text { Indexes for size of gov- } \\
\text { ernement, security of } \\
\text { property rights, free- } \\
\text { dom to trade interna- } \\
\text { tionally (Fraser Insti- } \\
\text { tute, Freedom House) }\end{array}$ & $\begin{array}{l}\text { Ashby } \quad(2010) \\
\text { Naghsh Nejad and } \\
\text { Young (2015) Melku- } \\
\text { mian (2009) }\end{array}$ \\
\hline & Informal & Corruption & $\begin{array}{l}\text { Indexes of Corruption } \\
\text { based on surveys } \\
\text { (Transparency Inter- } \\
\text { national) }\end{array}$ & $\begin{array}{l}\text { Poprawe (2015) Di- } \\
\text { mant et al. (2013a) } \\
\text { Cooray and Schnei- } \\
\text { der (2014) Rowlands } \\
(1999)\end{array}$ \\
\hline
\end{tabular}


This section aimed at giving a broad definition of institutions. In general, institutions are perceived as "rules of the game" but these rules can be seen as "habits of thought" (Veblen, 2007) or "beliefs and modes of behavior" (Durkheim, 1982) and they are not necessarily compulsory rules, as laws and regulations. They are at the same time coordination tools and regulation of conflicts devices and they can be codified or not and explicit. They are obviously a constraint for individuals, because they define what each one should do, in order to be better coordinated with others. In "old institutionalism" the emphasis is on the influence of institutions on individuals: individuals are made by the institutions, they are not the point of departure of the analysis. More precisely "Institutions are seen as a crucial part of the cognitive processes through which sense data are perceived and made meaningful by agents. Indeed $(. .$.$) rationality itself is regarded as reliant upon institutional props"$ (Hodgson, 1998, p. 180). On the contrary, "new institutionalism" takes individuals as given and studies how the institutions appear as a result of the strategies of individuals, considered as the elemental building blocks in the economic theory: "New insitutionalist project is the attempt to explain the emergence of institutions, such as the firm or the state, by reference to a model of rational individual behavior (...). An initial institution-free "state of nature" is assumed. The explanatory movement is from individuals to institutions, taking individuals as given" (Hodgson, 1998, p. 176).

In the rest of this chapter, we will study how institutions can influence or can be influenced by migration, which also evokes the question of the double-sided influence of institutions on individuals and of individuals on institutions. Because institutions influence the choices and even the taste and rationality of individuals, they will also influence the movement of people, their will to go out of their native countries or to go to a specific place (push and pull factors in migration). But because the individuals also influence institutions, the mobility of agents is going to change institutions, at the same time in destination countries and in source countries.

\section{Institutions as Determinants of Migration?}

Understanding the determinants of migration has always been a challenging task. Until recently, the literature has focused mainly on the economic and labor market dimension of migration. Since Hicks (1932), wage differentials are seen as the main determinants of migration. But recently, Clemens et al. (2014) note that the literature is more and more focused on the "cultural, social and personal dimension of migration" (Clemens et al., 2014, p. 122). In this frame, an emerging literature is analyzing the institutional determinants of migration. Our analysis is based on the distinction between "exit and voice" dichotomy of Hirschman (1970). First, we will see to which extent the exit option, meaning that individuals decide to migrate when institution are not satisfactory, is observed. As stated by Solimano (2005, p. 18), "in non-democracies, the mechanism of voice can be suppressed or become very costly to exercise. In that situation, individual that are unsatisfied or discontent with current political and economic conditions may choose to exit their home countries". In the next section, we will focus on the migrants' capacity to voice from abroad.

Our analysis will be made using the insights of gravity models. Ravenstein $(1885,1889)$ 
by proposing seven "laws of migration" was the first to use the intuition of the gravity model which will be developed several decades later by Tinbergen (1962) to explain bilateral trade flows. More recently, Anderson (2011) reviews the theoretical foundations and the use of gravity models to analyze both trade and migration flows. Beine et al. (2016) propose a "practical toolkit" for empirists using these models in migration. Traditional models of gravity have been built in analogy with the Newton Law of Gravity. A mass of goods, labor or other production factors, supplied in an origin country $o, Y_{o}$, is attracted by a mass of demand of goods, labor or other production factors in a destination country $d, Y_{d}$ but this flow is reduced by the distance between the two; $D_{o, d} \cdot{ }^{3}$ The rationale of the model is relatively intuitive. It is based on homogeneous agents who decide to migrate and choose the optimal destination which maximizes utility. This utility may depend on various factors, the main one is the level of income. But this utility function can easily be adapted to take into account non-monetary dimensions such as the quality of institutions. If bad institutions have detrimental impact on utility at home, then the model will predict a high probability to leave the country, consistently with the exit option in the Hirschman (1970) framework. We will also see that weak institutions may increase the cost of migration, which will lead to the opposite result.

Let's call $u_{o, o}$ the utility in country $o$ (for individuals from $o$ ) and $u_{o, d}$ the utility in country $d$ for individuals from country $o$. These two utility functions can take the following forms: ${ }^{4}$

$$
\begin{gathered}
u_{o, o}=\ln w_{o}+\ln I_{o}+A_{o}+\epsilon_{o} \\
u_{o, d}=\ln w_{d}+\ln I_{d}+A_{d}-C_{o, d}\left(I_{o}, I_{d}, A_{o}, A_{d}, A_{o, d}\right)+\epsilon_{d}
\end{gathered}
$$

where $w_{i}$ is the level of income in country $i, I_{i}$, the level of institutions in country $i, A_{i}$ a set of other country characteristics, and $C_{o, d}$ migration costs between country $o$ and $d$. These costs are a function of levels of institutions, other country characteristics and bilateral characteristics with a direct impact on migration cost (distance, language, networks...). Note that these costs may be financial costs but also psychological, cultural or social costs. Each utility function includes an error term which follows an extreme value distribution (McFadden, 1974). Under this assumption, the probability for an individual from a country $i$ to migrate to a country $j$ is the ratio between the flow of migrants from $i$ to $j\left(N_{i, j}\right)$ over the total population of country $i\left(N_{i}\right)$ (living in $i$ or abroad).

$$
\operatorname{Pr}\left[u_{o, d}=\max _{k} u_{o, k}\right]=\frac{N_{o, d}}{N_{o}}=\frac{\exp \left[\ln w_{d}+\ln I_{d}+A_{d}-C_{o, d}\left(I_{o}, I_{d}, A_{o}, A_{d}, A_{o, d}\right)\right]}{\sum_{k} \exp \left[\ln w_{k}+\ln I_{k}+A_{k}-C_{o, k}\left(I_{o}, I_{k}, A_{o}, A_{k}, A_{o, k}\right)\right]}
$$

In the same way, the probability of staying home will be equal to the ratio between individuals with nationality $i$ living in $i$ and the total population of $i$.

$$
\frac{N_{o, o}}{N_{o}}=\frac{\exp \left[\ln w_{o}+\ln I_{o}+A_{o}\right]}{\sum_{k} \exp \left[\ln w_{k}+\ln I_{k}+A_{k}-C_{o, k}\left(I_{o}, I_{k}, A_{o}, A_{k}, A_{o, k}\right)\right]}
$$


The equilibrium migration rate is then:

$$
\frac{N_{o, d}}{N_{o, o}}=\frac{\exp \left[\ln w_{d}+\ln I_{d}+A_{d}-C_{o, d}\left(I_{o}, I_{d}, A_{o}, A_{d}, A_{o, d}\right)\right]}{\exp \left[\ln w_{o}+\ln I_{o}+A_{o}\right]}
$$

Taking logs and rearranging, we obtain:

$$
\ln \left(\frac{N_{o, d}}{N_{o, o}}\right)=\ln \left(\frac{w_{d}}{w_{o}}\right)+\ln \left(\frac{I_{d}}{I_{o}}\right)+A_{d}-A_{o}-C_{o, d}\left(I_{o}, I_{d}, A_{o}, A_{d}, A_{o, d}\right)
$$

Most empirical papers analyzing the impact of various institutions on migration use explicitly or implicitly such a model. In the next subsections, we will review the impact of different institutions on migration flows, using this income maximization framework as a reference to understand different possible channels.

\subsection{Economic and Political Institutions}

\subsubsection{Economic Institutions: Rule of Law, Property Rights and Corruption}

The first set of papers focus on economic institutions or "economic freedom", although this last concept is less clear and somehow broader than economic institutions. Ashby (2010) analyzes the role of economic and political freedom. ${ }^{5}$ Implicitly, he considers the possible impact of institutions on utility - as described in equation (6). Migrants can be attracted by countries with better institutions. He then takes into account freedom both in destination and origin countries, using the ratio between the two, respectively for economic and political freedom. He analyzes both the impact on migration stock in OECD countries in 2000 and on migration flows between 2001 and 2006 for a sample of 56 countries. Political freedom is measured through the average between the political and civil rights score of Freedom House. Economic freedom is measured through the index constructed by Gwartney et al. (2007). He finds that economic freedom has a positive impact on migration flows. As the author used the ratio between economic freedom in destination and origin countries, this effect may come either from the positive impact of economic freedom in destination countries or the negative impact of economic freedom in origin countries. This question is not addressed in the paper but Naghsh Nejad and Young (2015) indirectly offer an answer, with the finding that economic freedom in destination countries is a pull factor for migrants. They use bilateral migration flows between 77 countries, including flows from and to non-OECD countries. They find that "migrants are attracted to destinations with sounder currencies, less burdensome regulations, and stronger property rights and legal systems" and do not find significant differences regarding the impact of economic freedom between skilled and unskilled individuals. Nevertheless, Melkumian (2009) also finds that economic freedom in origin countries is a significant determinant of migration towards the United States.

Corruption is a signal of weak institutions. Poprawe (2015) analyzes the effect of corruption in origin countries on bilateral migration flows. Using a large dataset covering 230 countries, she finds that corruption is a significant push factor, consistent with the exit option in the Hirschman (1970) framework. The main explanation provided by the author is that "countries with high levels of corruption provide a less secure business environment 
and worse working conditions and encourage individuals to move to countries where less corruption is present" (Poprawe, 2015, p. 339). Dimant et al. (2013a) find similar results on a panel of 111 countries over the 1985-2000 period. They find a stronger effect of skilled individuals, as corruption is supposed to decrease returns to education. Cooray and Schneider (2014) also find heterogeneous effects depending on the skill-level over the 1995-2010 period (the set of countries is not specified). If they find a positive relation between corruption and migration of high-skilled workers, they find an inverted-U shape relation for workers with medium or low skills. Their explanation is that increased inequalities generated by corruption may increase liquidity constraints for low and medium skilled workers, thus reducing their emigration rate. This inverted- $U$ shape relation is also found by Rowlands (1999), although with a different interpretation. She argues that "the effects of corruption on the incentive to migrate dominate the effect of administrative barriers for high levels of corruption, with the reverse being true for low levels of corruption" (Rowlands, 1999, p. 1484).

Lastly, Bergh et al. (2015) uses Worldwide Governance Indicators (Kaufmann et al., 2011), measuring both political and economic institutions. The set of indexes includes government effectiveness, control of corruption, regulatory quality, rule of law, political stability, and voice and accountability. In this paper, institutions are supposed to have two effects: it may have intrinsic value for people, entering into their utility function, which may have an impact on their decision to migrate. This first reason is very similar to the theoretical assumptions described before. The second reason is more specific. According to these authors, institutions are a signal for migrants to forecast future level of development. In equation (6), it would mean that institutions are seen as a proxy of $w_{i}$ - or more precisely, $E\left(w_{i}\right)$. According to this assumption, institutions may have a better explanatory power than current income as migration decisions are mainly based on long-term prospects. Using a gravity model with spatial approach, they find that institutions are a strong push factor of emigration. The impact of institutions in destination countries is narrower. Only effective bureaucracy and control of corruption are also robust pull factors of migration. The authors explain this heterogeneous effects between institutions in origin and destination by the lower level of information regarding institutions in potential destinations. When controlling for institutions, the level of income plays a much lower role in explaining migration.

\subsubsection{Political and Civil Rights}

Some papers focus more specifically on political institutions such as the political regime or the level of civil rights. As already mentioned, some papers study both economic and political institutions (Ashby, 2010; Naghsh Nejad and Young, 2015; Bergh et al., 2015). Ashby (2010) and Naghsh Nejad and Young (2015) argue that economic institutions are a stronger predictor of migrations than political institutions as the latter are not significant when controlling for economic institutions. But other papers do find a specific impact of political institutions.

Bertocchi and Strozzi (2008) use a dataset on 19th century migration and consider the level of democracy and the extension of suffrage as proxies of political institutions. They also measure the influence of institutions specifically targeted at attracting migrants, such 
as the kind of citizenship laws, land distribution policy, public education policy and immigration policy attitudes. They focus on the role of institutions in destination countries. ${ }^{6}$ They control for the potential endogeneity of political institutions, using initial citizenship laws, education policies, migration policy attitudes (i.e., their value in the first decade), and the dummy capturing colonization, as instruments. They find that institutions in destination countries ware a strong pull factor, even after controlling for income. They also find a distinct and significant impact of political institutions and institutions for attracting migrants. Solimano (2005) studies the determinants of migration from and to Argentina in the 20th century - considering Europe as the main region of immigration and emigration for Argentina. His measure of net migration is the difference between immigration inflows and emigration from Argentina. He finds a negative relation between authoritarianism in recipient countries and migration, consistent with the result of Bertocchi and Strozzi (2008) for the 19th century. But as he focuses on net migration, we do not know if this effect is driven by a pull or a push effect.

Karemera et al. (2000) focus on migration into the United States and test the impact of origin countries characteristics. Using different proxies of political and civil rights, they find that freer countries tend to be origins of large emigration flows. This result is clearly in contradiction with the exit option described by Hirschman (1970). The authors argue that less civil and political rights are associated with increased restrictions on residents' travel abroad. In that sense, less civil and political rights will increase migration costs and therefore reduce the probability to migrate. If we come back to equation (6), institutions have only an effect on $C_{o, d}$. Vogler and Rotte (2000) find comparable results for migration to Germany between 1981 to 1995. They find a negative relation between political and civil rights in origin countries and migration to Germany. ${ }^{7}$

Theoretically, these results bring an interesting perspective: the role played by institutions is twofold. First, institutions may have a direct impact on utility as described above. But they can have an indirect effect on migration costs which may explain the ambiguous results regarding the final impact of political institutions on migration. To come back to the income maximization framework, it means that the influence of institutions can have three distinct theoretical impacts: (1) a direct impact on utility in destination countries, (2) a direct impact on utility in origin countries, and (3) an impact on the migration cost, as modeled in equation (6).

In a study on GDP, democratization and emigration in Fiji, Narayan and Smyth (2005) find no impact of democratization on emigration in the short run, while they find a negative impact in the long run. One interpretation is that these two forces - the migration cost and the utility impact of democratization - may play a different role in the short and the long run. The latter is more likely to be observed in the long run, thus explaining the result in Fiji; while the former is more likely to be observed in the short run, thus explaining the result of Karemera et al. (2000) or Vogler and Rotte (2000). It may also explain why Rowlands (1999) finds no significant impact of civil liberties on emigration.

An illustrative example of these mechanisms can be the Arab Spring which offered a natural experiment where democratization and migration have been observed conjointly. Some have argued that democratization leads to a new wave of migration, which is consistent 
with the cost hypothesis where democratization reduces the cost of migration. However, Fargues and Fandrich (2012) challenge this view, arguing that "migration to Europe has not been accelerated by the Arab Spring, apart from a short-lived movement from Tunisia, but has simply continued along previous trends. In sharp contrast, migration within the Southern Mediterranean has been deeply impacted by the events as outflows of migrants and refugees fled instability and violence in Libya and Syria." In other words, large migration flows observed from these regions are the result of political instability and conflicts much more than the democratization process. Nevertheless, more studies would be needed to assess the causal impact of democratization in Arab countries on emigration.

This last hypothesis is consistent with the study of Dutta and Roy (2011) on the effect of political stability on high-skill emigration rate. Using a panel of 118 developing and developed countries, Dutta and Roy (2011) find that political stability is associated with a lower emigration rate for high-skilled workers. Thus, political stability decreases the likelihood of brain drain. In order to measure political stability, they use the country specific political risk indicators from the International Country Risk Guide (ICRG), including measures of government stability, socio-economic conditions, investment profile, internal conflict and ethnic tensions.

\subsection{Social Institutions}

In this section, we will focus on social institutions for women on the one hand, and the role of labor market institutions and social protection on the other.

\subsubsection{Gender Inequality}

The gender dimension of migration has been studied for a long time. Among the seven laws of migration of Ravenstein $(1885,1889)$, one stipulates that women are over-represented in short-term migration (Ravenstein, 1889, p. 288). However, until the sixties, women migration was perceived as dependent movers, as summarized by Lee (1966, p. 51) "not all persons who migrate reach that decision themselves. Children are carried along by their parents, willy-nilly, and wives accompany their husbands though it tears them away from environments they love". According to Lauby and Stark (1988), it may explain why the literature has ignored specific factors of women migration. Research in migration have broaden the scope, following what has been called the feminization of migration (Pedraza, 1991; Morrison et al., 2007). The original idea of Ravenstein that women were over-represented in (short-term) migration has been tested by several papers (Dumont et al., 2007; Docquier et al., 2012).

Weak social institutions for women lead to gender inequality and discrimination. A first strand of the literature argues that gender discrimination may turn into a push factor, by reducing utility at home (for women). Improving social institutions for women will therefore reduce migration as it will increase the utility of staying home. In a study on Mexico, Kanaiaupuni (2000, p. 1337) states that "educated women experience great gender discrimination and few occupational rewards in Mexico and, therefore, may be more likely to migrate across the border where they will earn greater wages than they would otherwise". Pedraza (1991, p. 309) argues that the act of migrating can be a way of escaping total dependence on their 
husbands, based on a study in the Dominican Republic. In the new economics of Migration (Stark, 1991) where migration is seen as a collective decision, female migration may be preferred to male migration if (i) women are sending back more remittances than men, if (ii) female migrants earn steadier income than men, or if (iii) the opportunity cost is lower for women due to poor labor perspectives in source countries. All these hypothesis are consistent with the idea that institutions - here social institutions for women - may have a direct effect on utilities at home and in potential destination countries. Bang and Mitra (2011) measure both the influence of institutional quality and gender equality. For the latter, they build an original index based on the share of women's income, fraction of women in parliament, the male female literacy rate gap, the male female secondary enrollment gap, the fertility rate and female labor force participation rate. They distinguish between equality of access - literacy, enrollment and fertility - and equality of outcome - labor force, income share and parliamentary representation. They find a strong negative relation between equality of access and female brain drain (while the effect of equality of outcome is not significant).

A second strand of the literature sees the potential impact of weak social institutions for women - or high gender discrimination - on the cost of migration. As Piper (2005) state, it may be less acceptable for women to move out and travel on their own - which will increase their psychological or social cost of migration. Kanaiaupuni (2000) notes that, due to reasons of tradition, gender inequality may create a bias in the selection process within the household and reduce female migration. Baudassé and Bazillier (2014) build several indexes of gender equality in the work place and test their influence on migration flows. They want to discriminate between what they call the "push factor hypothesis" - gender equality enters directly in the utility function of potential migrants - and the "selection process hypothesis" - gender inequality adds a specific migration cost for women. They do not find a significant impact on overall migration but find a negative impact of gender equality on the migration of men and a positive impact on the migration of women. Interestingly, they find that gender equality tends to increase relatively more migration of skilled women and to decrease relatively more migration of low-skilled men. The overall skill-level of migrants is therefore increasing. Their study is based on a panel of developing and developed countries over the 1991-2001 period. Ferrant and Tuccio (2015) studies the two-way relationship between South-South migration and "discrimination against women in social institutions". They use the original Social Institutions and Gender Index (SIGI) built by the OECD Development Center. The index takes into account dimensions such as family code, physical integrity, son bias, restricted resources and entitlements, and restricted civil liberties. They find a negative link between discrimination in origin countries and migration of women. This is consistent with the cost hypothesis and the result obtained by Baudassé and Bazillier (2014). They also find a negative link with discrimination in destination countries, which is consistent with the idea that discrimination has a negative impact on utility - a lower value of $I_{d}$ in equation (6)). Contrary to Baudassé and Bazillier (2014) they do not find significant impact on male migration. The geographical scope and the specific type of discrimination are not the same, which may explain such differences.

Naghsh Nejad and Young (2014) may conciliate the two strands of the literature by finding a non-linear relation between gender equality and female brain drain. They use a 
broader Womens' Right Index from the Cingranelli-Richards (CIRI) Human Rights dataset. They use a typical random utility model, very similar to the one described in the introduction of this section and show theoretically this non-linear relation, as soon as the utility and the cost components of discrimination are taken into account conjointly. Empirically, they find an inverted U-shape relation between the "women's right gap" - defined as the ratio of women's rights in destination countries over women's rights in origin countries - and female brain drain. In other words, for low level of this gap, an increase of this gap - a decrease of gender equality in origin or an increase of gender equality in destination - would lead to an increase of migration for high-skilled women. Beyond a certain level, the relation turns negative. If the gap is too large, the cost impact of gender discrimination becomes dominant.

\subsubsection{Social Protection and Labor Market Institutions}

The social protection system is a component of overall institutions. A large literature on welfare migration has studied whether immigrants are more likely to move to countries with generous welfare systems. ${ }^{8}$ This literature has focused mainly on the level of public spending and not the type of institutions as such. Furthermore, it focuses on the role of social protection in destination countries. The logic is very straightforward. Following our baseline model, the idea of this literature is to test whether higher level of public spending in destination countries $\left(I_{d}\right)$ has an effect on migrants' utility in destination $\left(u_{d}\right)$, which would explain the the migration rate registered by the destination country. We will briefly review this literature before presenting more deeply the literature focusing explicitly on the role of institutions and not social spending.

The seminal paper is Borjas (1999) who studies the impact of welfare on immigration into the United States. The so-called "welfare magnet hypothesis" is that immigrants prefer to locate in countries with generous welfare provisions in order to insure themselves against labor market risks. An alternative way to model such effect in equation (6) would be to consider that welfare provisions allow to reduce the standard deviation of $w_{d}$, which may be an additional factor of utility for risk-adverse migrants. Generous welfare state may attract immigrants that otherwise would have not migrated and social safety nets may also retain migrants who would return to their country otherwise. The United States is a very interesting case: migrants choose to go to the US and then choose the State in which they will live. The cost of migration for new migrants has already been paid, the cost of choosing one state or the other is negligible. It is the main difference with US natives. For them, it is much more costly to change state to get social benefits as they have to pay a new migration costs. In other words, welfare is likely to be a more important factor for migrants than for natives. He shows that native welfare recipients tend to be much more dispersed across states than migrants.

Two dimensions are very important to understand welfare migration. First, it relies on a good information on welfare benefits and social protection system in the destination country. The role of networks and diaspora (Beine et al., 2011) is likely to be very important. The larger the diaspora, the more likely the phenomenon of welfare migration. The second dimension is the role of migration policies. Migrants are restricted in their choice of destination countries. And governments may take into consideration their welfare system when 
setting their migration policy. Razin and Wahba (2015) propose a distinction between free migration and restricted migration regimes. In the former, generosity of the welfare state attracts relatively more unskilled migrants as they expect to gain more from welfare benefits than what they expect to pay in taxes. On the contrary, skilled migrants may be deterred by the generosity of the welfare state as they are more likely to be net contributors to the welfare state. In restricted migration regimes, voters will favor skilled immigration because the fiscal burden is supposed to be lower or even negative.

The empirical literature on welfare migration has focused on two distinct dimensions: (1) Are migrants more likely to be welfare recipients than natives? (2) Are welfare states a magnet for migrants? Concerning the former, Giulietti and Wahba (2013) identify six theoretical reasons explaining why it may be the case: (1) self-selection of migrants, (2) migration-specific effects, (3) discrimination, (4) network effects, (5) non-portability of entitlements, and (6) reduced wages. However empirical evidence is weak. If there is small evidence for the US (Borjas and Trejo, 1993; Borjas and Hilton, 1996; Borjas, 1999), results are much more mixed for Europe (Hansen and Lofstrom, 2003; Barrett and McCarthy, 2008; Barrett et al., 2013b; Boeri, 2010; Pellizzari, 2013; Barrett et al., 2013a; Blanchflower and Lawton, 2009; Constant, 2011).

Concerning the second dimension: is welfare a magnet for migrants?, empirical evidence is also very mixed and the effects seem to be small (or negligible). De Giorgi and Pellizzari (2009) find a significant but very small effect for immigration in Europe. Pedersen et al. (2008) do not find any significant impact of social expenditures on immigration in OECD countries. They argue that immigration policies may have prevented the potential adverse selection of migrants. Brücker et al. (2002) focus on the selectivity of migrants and show that countries with low social spending tend to attract skilled-migrants since taxes are low in these countries while welfare-generous countries tend to attract low skilled workers. The main challenge in this literature is to take into account the endogeneity of public spending as it may be affected by migration flows. Böheim and Mayr (2005) show that low-skilled immigration decreases public spending while high-skilled migration increases it. Giulietti et al. (2013) take explicitly into account this endogeneity problem in a study on immigration into the European Union. While they obtain a positive correlation between immigration flows from non-EU countries and unemployment benefits, they find a nil causal impact of such benefits on migration flows.

An emerging literature is focusing more specifically on the role of some specific labor market institutions. Baudassé and Bazillier (2010) propose to study the impact of trade union rights in origin countries on migration. They argue that trade union rights can improve welfare of low skilled workers as it tends to reinforce their bargaining power and therefore their relative income. But, in the presence of a large informal sector, trade union rights tend to be more effective in the formal sector. As skilled workers are more likely to be formal, they can also benefit from this situation. The authors propose several indexes of trade union rights and show the link with migration. Trade union rights in origin countries are shown to be negatively correlated with migration. Effects are both significant for low skilled and high skilled workers, but not for workers with intermediate skills. The authors argue that it is likely to be the result of these two forces - the wage premium for low 
wages combined with the formal wage premium. However, trade union rights may also be associated with more social tensions. In that case, results are reversed: more social tensions are associated with more migration. Overall, these results are consistent with the prediction of the theoretical model where $I_{o}$ tends to reduce migration (see equation 6 ).

Geis et al. (2013) focus on the role of different labor market institutions in destination countries - France, Germany, the UK, and the USA - using micro data. Employment protection is found to have a positive impact of immigration and the decision to stay in one given country. On the contrary, union coverage and unemployment benefits tend to have negative effects (in contradiction with the assumption of welfare migration). Theoretically, these two results can be explained through the very simple model presented in the introduction of this section. First, labor market institutions may increase utility of migrants in destination $\left(I_{d}\right)$, therefore increase migration flows. But it can be a cost if it impedes some migrants to find a job. According to the insider-outsider theory, a protected labor market tends to exclude outsiders, which partly consist of migrants. In this case, it will decrease the expected value of $w_{j}$, thereby decreasing migration. Union coverage has a positive impact on the decision to stay. Once migrants decide to be insiders, they may enhance their appreciation of union coverage.

One drawback of their analysis is that they do not take into account the potential impact of labor market institutions in origin countries. For instance, even in the case of a South-North migration, employment protection may be higher in origin than in destination countries - see Freeman (2010) for a discussion on labor market institutions in developing countries. Bazillier and Moullan $(2010,2012)$ propose to measure the effect of employment protection differential. They show that this differential tends to be negatively associated with migration flows. The higher the gap between employment protection in origin and destination, the lower the migration flows. This gap is seen as a "social distance" which has a negative impact on the capacity of migrants to be integrated in the labor market. If this distance is too high, the expected income in the destination country may be much lower and therefore has a negative impact on migration. Lastly, Giulietti (2014) studies the potential pull impact of the minimum wage, based on the case of immigration into the US in 1996-1997 and 2007-2009. He exploits the between-states variation in minimum wages and takes into account endogeneity of minimum wage variations. He shows that minimum wage tends to attract low-skilled workers. This pull effect is explained by the direct impact on their wages, without harming their potential employment outcomes. It does not have any effect on migration of high-skilled individuals, nor on illegal migration - as illegal migrants are not supposed to benefit from minimum wage.

To conclude this section, we can say that institutions are an important determinant of migration that should be taken into account. However the mechanisms are very heterogeneous and the effects very diverse. We identified three main channels. First, institutions are likely to have a direct effect on utility, both in origin and destination countries. Good institutions in origin tend to reduce migration while institutions in destination increase it. Second, they may have an indirect effect on income or the expected income. Third, weak institutions may increase migration costs. In that case, an improvement of the institutional framework may increase migration. As for the impact on other economic outcomes, the ef- 
fect of institutions may largely differ and it is necessary to study more in depth the specific impact of each institution. Overall, it appears that it is very important to have a look, not only at institutions in destination countries, but also in origin countries.

\section{The Impact of Migration on Institutions}

The contribution of international migration to development has risen steadily since the theoretical works in the late 1990s, showing the potential human capital gain for countries concerned by skilled emigration (Mountford, 1997; Stark et al., 1997, as early works). The emigration flows in general, and the skilled ones in particular, originally analyzed as a loss for the sending countries came to be seen as something beneficial. Several development dimensions related to international migration were investigated. In this section, we will focus firstly on the causal relationship between migration and institutions and provide the possible mechanisms involved in the impact of migrants on their home country institutions. ${ }^{9}$ Next, we will examine their effect on the institutions in the destination countries.

\subsection{Why do Migrants may Influence their Home Country Institutions?}

Beyond purely ideological or philanthropic considerations, some arguments can explain the interest of migrants for the emergence of the best quality of institutions in their origin country. One argument is that migrants who intend to return home for different reasons are particularly concerned with the quality of institutions in their home country. Indeed, entrepreneurs rank high among those who return to home and need that effective institutions should guarantee a good business environment and protect them from abuses. ${ }^{10}$ Another reason is that migrants by making efforts for institutional improvement, seek that their family and friends sustain themselves, for they are aware of their inability to perpetually ensure the needs of their relatives.

Migration policies more and more restrictive also affect the way individuals decide in favor of enhancing institutions in their home country as they face difficulties to bring their families. In support of this, Licuanan et al. (2015) emphasize the xenophobic behavior in explaining the determinants of collective remittances to the Philippines.

Beyond purely ideological or philanthropic considerations, some arguments can explain the interest of migrants in wanting to increase the quality of institutions in their origin country. One argument is that migrants may intend to return home for different reasons. Indeed, entrepreneurs rank high among those who return home and need effective institutions that guarantee a good business environment and protect them from abuses. ${ }^{11}$ Another reason is that migrants make efforts for institutional improvement because they want their families and friends to become financially autonomous, being aware of their inability to perpetually ensure the needs of their relatives.

More and more restrictive migration policies also affect the way individuals decide in favor of enhancing institutions in their home country as harsh policies translate into difficulties to bring along their families. In support of this, Licuanan et al. (2015) emphasize the xenophobic behavior to explain the determinants of collective remittances to the Philippines. 
Finally, the exposure to good institutions in the destination countries and their underlying consequences in terms of individuals' well-being is another explanation of migrants' motives to stimulate the institutional change in their home country. The seminal work of Spilimbergo (2009) offers empirical evidence on how the institutional environments in the destination countries is essential for foreign students to encourage democratic diffusion in their home country. He collects data on the foreign students from UNESCO Statistical Yearbook between 1960 and 2003 for a large number of countries including several developing countries. This dataset counts 2 million foreign students in the world in 2002, a significant rise compared to 50000, the number of foreign students 50 years early. Destination countries are democratically heterogeneous and this heterogeneity allows Spilimbergo to compute an index indicating on average the level of democracy to which the foreign students of a given origin country are exposed to around the world. This index ranges from 0 to 1 and values close to 1 mean more democratic destination countries for the foreign students from a given origin country, while values close to zero indicate for a given origin country that its students abroad are largely settled in countries with dictatorships. It is worth noting that the level of democracy in the destination countries the foreign students opt for is on average higher than the one in their origin country. This is suggestive of the attractiveness of good institutions in the choice of a given destination country by migrants, as mentioned above. Testing an interaction variable that captures the marginal effect of foreign students subject to the level of democracy in the destination countries in a dynamic model, he finds a positive and highly significant coefficient. In none of the specifications the coefficients on students abroad are significant, while democracy in the destination countries is positive and highly significant. In terms of magnitude, a rise of 0.5 percent in the number of students abroad over the total population induces the democratic index to rise by 0.08 . These results hold after several robustness checks.

Spilimbergo identified numerous channels through which foreign-educated individuals may influence the level of democracy in their home country. The choice of democratic regimes can prevail in an environment where foreign-educated individuals are the few existing technocrats. As educated leaders, the probability is high that they will induce reforms. They disseminate new ideas at home that go against the dictatorship. And at the same time, their access to external media discourages repressive actions from dictatorial regimes. Finally, foreign-educated individuals enjoy a preferential relationship with foreign governments with which they share democratic values. Although Spilimbergo provides potential hypotheses, he does not suggest a specific channel that comes into play in his empirical evidence.

In a related work, Fidrmuc and Doyle (2004) take advantage of a dataset on votes cast by migrants from Czech and Poland in national elections in their respective country. They observe that these migrants differ from their counterparts remaining home in terms of their voting preferences. Of the three possible factors to explain migrants voting behavior namely economic self-selection, political self-selection and the institutional environment of the host countries - the latter is consistent with their empirical estimations. This implies that migrants bring their political preferences into line with those prevailing in the destination country, especially democracy and economic freedom values. 


\subsection{How do Migrants Influence Home Country Institutions? \\ 4.2.1. Size and Skill Composition Effects}

The first key point one can think of when investigating the impact of migrants on domestic institutions is their importance in terms of number and skills. Unlike the individual actions by way of remittances, collective actions of migrants seem essential if their goal is to enhance institutions. In this respect, sending countries with a high emigration rate would be more prone to institutional change. Docquier et al. (2016) supplie an empirical support for this view. Their goal is to assess how the emigration rate influences the quality of institutions. Using a five-year interval emigration data of Brücker et al. (2013), they regress the emigration rate on a set of institutional indicators, including other control variables. One challenge in the relationship between emigration and institutional variables is the reverse causality. The quality of institutions could be one factor of the choice of migrating, as it was discussed previously. Therefore it is crucial to address this issue by using a two-stage least squares (2SLS) estimation method which implies finding valid instruments. Proposing instruments for emigration is a difficult task and all the more for panel data which require time-varying instruments. A cross-sectional framework is first adopted by the authors to use a geography-based prediction of bilateral stocks to instrument the emigration rate. A cross-sectional framework is first adopted by the authors who use a geography-based prediction of bilateral stocks to instrument the emigration rate. Their instrumental strategy follows studies related to migration and trade. Given that they used panel data, they have also performed pooled and GMM system estimators.

Their overall estimations are suggestive of a positive and significant impact of emigration rate on a series of institutional variables ${ }^{12}$ regardless of the level of democracy in the destination countries. ${ }^{13}$ This result implies only that the total emigration rate has a size effect on the home country institutions; not that the characteristics in the destination countries are irrelevant. Docquier et al. (2016) run a regression in which the emigration rate is reduced respectively to high-skill and low-skill emigrants in order to test for heterogeneous effects. Moreover, they consider the interplay of the total emigration rate and the share of high-skill emigrants. Finally, they limit their sample respectively to countries with high and low educated emigrants. They find that the skill composition of the stock of migrants is not relevant.

Beine and Sekkat (2013) also examine the impact of emigration on institutions in the origin countries for a large number of developed and developing countries. They regress the migration rates of 1990 on (the change of) four governance indicators of Kaufmann et al. (2004) over the 1994-2004 period. They find that the impact of emigration rate on the institutional indicators of Kaufmann may be positive or negative. Unlike Docquier et al. (2016), in their regressions skilled emigrants affect more the quality of institutions than low skilled ones, indicating the skill composition heterogeneity. However, the two studies are not entirely comparable as they differ in terms of data used, the instrumental strategy adopted and the covered time period.

Li and McHale $(2006,2009)$ are among early works to posit the positive effects of emigration on the development of domestic institutions. Using Docquier et al. (2007) database, they propose empirical estimations of the impact of emigration on the quality of institutions 
proxied by the six governance indicators of Kaufmann et al. (2007). They divide these governance indicators into political institutions comprising voice and accountability and absence of violence/terrorism and economic institutions formed by the four remaining indicators: Government Effectiveness, Regulatory Quality, Rule of law and Control of Corruption. As there is reverse causality between the emigration-institutions relationship, they use three geography-based instruments namely the logarithm of a country's land mass, a dummy variable for an island country, and the surface distance from the country's capital to the capital of the United States. They find that skilled immigrants positively and significantly affect the quality of political institutions, while a negative and weak effect is observed on the quality of economic institutions. To explain their empirical conclusions, the authors allege that "emigration thins the ranks of individuals that are both a key sources of demand for productivity enhancing institutions and direct suppliers of institution-building skills".

\subsubsection{Political Influence on those Remaining Home}

Pushing the analysis one step further, the study of Mahmoud et al. (2013) has the advantage of pointing out a specific channel through which migrants act to improve the institutions in their home country. They examine how migration affects elections results in Moldova, a former Soviet Republic, with individual survey and administrative data. Moldova offers a quasi-experimental framework because emigrants from Moldova choose two main destinations - the European Union or Russia - quite different in terms of democracy standards. The first issue these authors address is the selection bias. Diaspora or migrants networks are determinant in the destination choice of candidate migrants. As the goal is to look at how political values in the host countries of Moldovan emigrants affect their political preferences, one may question the political self-selection: candidate migrants initially choose destination countries where their political or institutional preferences are implemented. It is also possible that a set of omitted variables influences migration and voting patterns even at the community level. Mahmoud et al. (2013) argue that the decrease of communist votes in communities with significant emigration to the west does not support the individual selfselection - that is migrants with stronger preferences for democracy move to democratic destinations. Indeed, in the presence of individual self-selection effect there should be more individuals with communist preferences in the community. They also control for the premigration political preferences to take into account the risk of political selection at the community level - the political trend of the community. They also controlled for economic changes (crisis) and account for district fixed effects. Their results suggest that emigration to the west negatively and significantly impacts the votes obtained by the communist party in the 2009-2010 election in Moldova. Another important result is that the preferences transmitted by migrants do not remain confined to the family circle or the group of friends. They observe a democratic externality that significantly affects non-migrants households and also less educated communities.

\subsubsection{Remittances Effects}

Pfutze (2012) studies the causal impact between migration to the United States and the probability of parties in opposition to defeat the incumbent party - called Institutional 
Revolutionary Party (PRI) - in Mexican municipal elections. The author uses the 20002002 electoral cycle data comprising around 1982 municipalities to estimate an instrumental variable probit model and finds that migration significantly increases the likelihood of the opposition parties to win municipal election for the first time. More specifically, a $1 \%$ rise of migrant households in municipalities led by the PRI increases by approximately 0,5\% the probability of victory. Pfutze puts forward two channels to explain how migration may affect electoral outcomes in the case of Mexico. The first channel, in line with other studies, is the social remittances that are the transfers of ideas and values from the destination to the origin country of migrants. The second channel, privileged by the author, has to do with the fact that remittances undermine the clientelistic behavior of the incumbent government. The logic is that as remittances increase the income of voters, the clientelistic transfers are less attractive unless the government increases their amount - which would be very difficult if the government faces budget constraints.

In support of the argument that remittances decrease the political manipulation, Combes et al. (2015) regress the interaction term between remittances and election year dummy on the government consumption to GDP ratio for a panel of 70 young democracies developing countries over the period 1971-1998. They find a negative and significant coefficient of the interaction term meaning that remittances dampen the political business cycle (PBC). O'Mahony (2013) shows fluctuations in the volume of remittances to developing countries around the election years. Using a panel data of 81 developing countries over 1990-2005, she shows that remittances increase during election years and more increasingly in countries with low income and competitive elections. Tyburski (2012) studies the impact of remittances on corruption in 32 states of Mexico and finds that remittances reduce corruption, making the government more accountable. This study also fails to disentangle between several possible explanations.

However, the positive impact of remittances on governance is at odds with other empirical studies about the remittances curse, showing how remittances deteriorate the quality of governance. Using panel data for 11 countries over the period 1986-2010, Berdiev et al. (2013) show that remittances have a positive and significant impact on the level of corruption. Conducting a quasi-natural experiment, Ahmed (2013) shows that remittances deteriorate the quality of governance in the presence of weak democratic institutions. Abdih et al. (2012) show that remittances have a detrimental effect on some aspects of institutions such as the control of corruption, government effectiveness, rule of law - from Kaufman governance indicators. Tyburski (2014) argues that the detrimental effect of remittances on corruption needs to be qualified. According to him, the way migration affects the level of corruption has to do with the political institutions. In presence of closed regimes, remittances deteriorate corruption, while the dampening effect is observed in open regimes. Blattman and Miguel (2010) point out a very specific case in which diasporas, due to ethnic or religious motives, can fuel civil conflicts in their origin countries by financing rebels.

\subsubsection{Return Migration Effects}

Batista and Vicente (2011) examine in Cape Verde if the migration experience can play a role in individuals' choices to ask for political accountability. They design the following 
vote experiment: households were asked to send back a prestamped postcard they received, with the promise that if at least 50 percent of postcards were returned, the results of the survey of perceived corruption in public services will be made public via the national media. A tailored survey then helped distinguish the positive effect of international migration from other factors that can affect the demand for political accountability such as the distance to post mail, the confidence in surveyors, income and households characteristics. They find that the migration experience has a positive effect on demand for political accountability, with a larger effect if the migration experience took place in destination countries with a good quality of governance. In addition, returned migrants ask for more political accountability than current migrants. Compared to other empirical contributions, this study was able to focus on a specific channel: the demand side through which political institutions change may arise.

Chauvet and Mercier (2014) examine how Malian emigrants who returned home affect the participation and the electoral competitiveness proxied by the fragmentation of the vote and the winning margin. Their empirical strategy consists of 2SLS cross-sectional and two-period panel fixed-effect estimators. Consistent with other studies, they find that the electoral preferences of returnees go beyond their circle as they disseminate new political norms among non-migrants. It is important to stress that their positive correlation results between the stock of returnees and respectively participation rates and electoral competitiveness, are only valid for Malian returnees from non-African countries. This can be suggestive of the need for a significant difference between the sending and host countries at the institutional level, for an effective transfer of political norms. ${ }^{14}$

Return migration may also increase the number of elites in the origin country who can play a fundamental political role. In that respect, Mercier (2016) examines how the migration experience matters to the leadership of politicians. Her empirical analysis looks at how foreign education experience of leaders in power influences the level of democracy in their country. For this purpose, Mercier compiles a database on personal record of 932 politicians who were in power over the 1960-2004 period. Controlling for the profession and the level of education of the leaders, she shows that leaders educated abroad favor democracy in their country during their term of office.

\subsection{Do Migrants Deteriorate Institutions in Destination Countries?}

The question of whether migrants are beneficial or detrimental to destination countries represents an ongoing concern. When it comes to investigating the effect migrants may have on the destination countries, several studies assess it in terms of the increase or decrease in natives' welfare. The topics covered range from the impact of migrants on the wages and employment of natives or the welfare dependency of migrants, to the fiscal burden they constitute or the displacement of natives they may induce. ${ }^{15}$ Assuming that immigrants were not allowed to vote, an interesting investigation is to understand the way they affect the provision of public goods and indirectly the levels of taxation required to ensure continuity of social spending programs. According to Razin et al. (2002), voters (native-born populations) opt for lower tax burden and less redistribution in the presence of immigrants. These authors provide a theoretical analysis based on a median voter to predict that the 
preference of native-born taxpayers will overtake the ones of immigrants who prefer high taxes and more redistribution. Other studies relate the provision of public goods to the ethnic fractionalization. Alesina et al. (1999) link theoretically heterogeneous preferences across ethnic groups to the provision of public goods. Testing the model, they show a negative relationship between ethnic fragmentation and the share of spending devoted to public goods in U.S. cities. To explain why the welfare states are more common in Europe than in the United States, Alesina et al. (2001) argue that European countries are more ethnically homogeneous than the United States.

Some argue the most serious concern about immigration is its social impact on destination countries. Borjas (2015) wonders about the change in social norms and institutions with massive migration flows. In Borjas (2014), he had already argued that one may fear the negative effect of migration on institutions in the receiving countries since migrants can bring with them the bad institutions that impede the development process in their home countries. Putnam (2007) performs a cross-section analysis of the effect of immigration on trust in America. He finds that a high proportion of immigrants in a community reduces the mutual levels of trust between immigrants and natives. Also, the low level of trust induced by migration deteriorates trust among the natives. Collier (2013) also analyses some situations in which immigration is a threat to the social model in destination countries. ${ }^{16}$ For Collier, if the diversity brought by migrants is in some respects beneficial, it also generates problems. Norms brought by migrants can be opportunistic compared to norms in the destination countries. Collier adds that the way migrants affect the social model in the destination country depends on their total number and how quickly they adjust to the norms of the host country. ${ }^{17}$ The fact that migration can increase the number of people with low levels of trust, thereby creating an opportunistic behavior rather than the desirable cooperative one, can be a concern. Confronted with this concern, Collier argues that not all countries succeed in leading migrants to take on the norms of the new society. However, neither Collier nor Borjas provide empirical evidence about the negative institutional effect immigrants may have on the destination country due to their cultural and institutional practices. The former tells anecdotal cases in Great Britain. The latter simulates how the economic gains from open borders can turn into economic collapse when the bad institutions transferred by immigrants are taken into consideration.

The negative effect Borjas and Collier fear (i.e. that immigrants may have a negative impact on institutions) cannot be sustained on the basis of the aforementioned analytic framework of Hirschman (1970). Indeed, it would be surprising that people who leave their countries due to the bad quality of institutions may want to recreate them in the host country. However, testing the impact of immigration on destination countries, Dimant et al. (2013b) finds that the stock of migrants from corrupt countries is positively and significantly associated with corruption in destination countries. Cheong et al. (2007), criticize the idea that immigration flows and ethnic diversity are a threat to social cohesion in host countries. The fact that local population views social capital under threat of being destroyed by immigration result in a fear of multiculturalism created by political debates. They also present social capital as a social construction which varies over time in relation to the dominant political ideologies. Clark et al. (2015) test empirically whether immigrants 'travel' to the 
destination countries with the inefficient institutions of their origin country. The authors use the Economic Freedom of the World Annual Report of Gwartney and Lawson (2013) to test for the institutional effect of immigrants in destination countries. The authors run regression with a cross-section data of 110 countries and find a positive correlation between their explanatory variable, the immigration stock in 1990, and the dependent institutions variable, economic freedom in 2011. With difference-in-difference regressions on panel data including both time and year fixed effects, the authors find again a positive coefficient on the immigration flows. They conclude that their empirical analysis does not provide any evidence that migrants negatively impact institutions in destination countries when using the economic freedom aggregate.

\section{Conclusion}

This survey examines the two-way relationship between international migration and institutions. We first define what institutions are and distinguish different types of institutions. As we show in this chapter, the way that institutions impact migration and inversely, the way that migration affects institutions both in the origin and destination countries, may differ according to the social, economic or political institutions considered. We sustain that institutions are fundamental in explaining why people leave their country and their choice of a specific destination country. Institutions are therefore a front-line player in the decision to migrate and where to go to, at the same level as economic factors. This recognition of the role of institutions in determining human movement has some implications. Immigrants who have previously suffered from bad institutions in their origin country may want to change them in order to facilitate the daily life of their relatives or to make possible their return home. Next, we look at the impact that international migration may have on the quality of institutions in both the origin and the destination country. With regard to the migrants' effect on the home country institutions, there are more studies showing their beneficial effect than their detrimental one. We sustain a broader perspective according to which migration is more beneficial than detrimental for the origin countries. We also analyze the possible channels through which immigrants may affect the home country institutions. Looking at the impact of immigrants on the destination country institutions, we find that there are less rigorous empirical analyses compared to those related to the institutional impact in the origin country.

So what can we learn from the reverse causality between institutions - in the origin and destination countries - and international migration? First, economic and demographic factors are certainly not the whole story of the determinants of international migration. People migrate partly in search of good institutions that their origin country does not provide. Second, emphasizing that bad institutions in the origin countries constitute a push factor or that migrants are attracted by good institutions in the destination countries, does not mean that emigrants lose interest in asking for good institutions in their origin country. As we have shown, migrants contribute through several channels to the institutional development in their origin country: a point beyond the mutually exclusive exit and voice dichotomy of Hirschman (1970). This is important because much attention has been directed 
only to the economic impact of migrants on their home country. Third, policy intended to promote migration as a way to improve institutions in the destination countries must account for the immigrants' impact on destination countries. Although there is no certainty that immigrants negatively affect institutions in destination countries, this will not help to reduce restrictive migration policies. As return migration constitutes one channel through which migrants affect institutions in their home countries, migration policies in the destination countries promoting temporary migration can be an optimal trade-off between the reduction of the stock of migrants pursued by the destination countries and the diaspora-assisted development that the origin countries seek to exploit and encourage.

\section{Notes}

1 Note that the efforts to establish appropriate institutions, for example democracy, can also favor emigration.

${ }^{2}$ In their book "Why Nations Fail", Acemoglu and Robinson (2013) divide political and economic institutions into inclusive and extractive ones. Economic institutions are inclusive if private property is secured, system law is unbiased and public services are provided. Inclusive institutions not only benefit everyone, but they also favour education and technology which are determinant for economic growth. On the other hand, extractive economic institutions are designed such that the wealth produced in the society is used for the benefit of a handful of people. The inclusive-extractive dichotomy is also made with political institutions. Centralization and Pluralism characterize inclusive political institutions while non-centralization and the lack of pluralism characterize extractive political institutions. Economic and political institutions are interconnected. Where political institutions are extractive, economic institutions are extractive too. In fact, the choice of extractive economic institutions without strong opposition is made possible by extractive political institutions under which the political power is controlled by the elites. Once extractive economic institutions are in place, they will favour extractive political institutions, generating a vicious circle. By the same logic, inclusive economic institutions are the result of inclusive political institutions; in turn, inclusive economic institutions generate inclusive political institutions. These authors argue that extractive institutions (political or economic) together with inclusive institutions represent an unstable combination. According to them, Barbados was an example of the failure of extractive economic institutions under inclusive political institutions. And inclusive economic institutions under extractive political institutions are also not sustainable since the former may turn into extractive political institutions to serve the interests of the elites. If not, there will be a shift from extractive political institutions to inclusive ones.

3 If his type of modeling has been criticized by the lack of theoretical foundations (Anderson, 1979; Anderson and Van Wincoop, 2003), the Roy (1951) model and the income maximization framework can provide a useful theoretical background to analyze the potential influence of monetary and non-monetary dimensions. It is based on the random utility model of McFadden (1974), then developed by Borjas (1987), Grogger and Hanson (2011) or Beine et al. (2011). It has been used to explain the role of wage differential (Grogger and Hanson, 2011), the influence of networks (Beine et al., 2011), the brain drain (Gibson and McKenzie, 2011), or climate change (Beine and Parsons, 2015). We will use this framework to analyze the impact of various institutions on migration.

${ }^{4}$ We assume that the utility function is log linear in $w$ and $I$.

${ }^{5}$ He defines economic freedom as "the freedom to benefit from the fruits of one's labor through voluntary exchange while allowing this same right to others. A society that enjoys economic freedom is organized as a competitive free market in which economic resources are allocated through the private decisions of individuals rather than the bureaucratic regulations of government" (Ashby, 2010, p. 51). Political freedom is defined as "the absence of coercion by others and by the government. In this sense, political freedom (...) is based on protection for the individual. Such protections are often associated with civil liberties, which include freedom of religion, freedom of assembly, rule of law, freedom of the press, and personal autonomy" (Ashby, 2010, p. 51). 
${ }^{6}$ Belgium, Denmark, France, Germany, Great Britain, Italy, the Netherlands, Norway, Portugal, Spain, Sweden, Australia, Canada, and the United States

7 They use Freedom House indexes. The lower the value of the index, the higher the level of political and civil rights. Therefore, the estimated coefficients are negative.

${ }^{8}$ See Giulietti and Wahba (2013) for an excellent survey specifically on this topic.

${ }^{9}$ If political institutions are widely discussed in this section, there exist several studies interested in the impact of migration on the fertility norms and gender inequality - often termed as social institutions - in the migrants' countries of origin. Fargues $(2006,2011)$ find that international migration impacts the demographic transition in the origin country of migrants. For other studies supporting the migration-induced transfer of fertility norms, see Beine et al. (2013); Bertoli and Marchetta (2015); Davis (2011); Lindstrom and Saucedo (2002); Lindstrom and Muñoz-Franco (2005). Ferrant and Tuccio (2015) show that the female migration is influenced by discriminatory social institutions, which are in turn shaped by the low or the high level of gender inequalities in the migrants' countries of destination. Lodigiani and Salomone (2015) evidence that female parliamentary representation is increased by international migration to countries where female political empowerment is high.

${ }^{10}$ About the involvement of migrants in entrepreneurial activities, see McCormick and Wahba (2001); Piracha and Vadean (2010); Marchetta (2012) among others.

${ }^{11}$ Concerning the involvement of migrants in entrepreneurial activities, see McCormick and Wahba (2001); Piracha and Vadean (2010); Marchetta (2012) among others.

${ }^{12}$ De facto institutional quality is impacted by the total emigration rate while there is no effect on de jure institutions.

${ }^{13}$ However, regressions distinguishing between OECD and non-OECD destinations have shown that only emigration to the former affects the home country institutions. The authors conclude that liberal democracies in the destination countries are an important factor in explaining the role of emigration in the home country institutions.

${ }^{14}$ Note that the positive participation rates specific to Malian returnees from non-African countries are more robust than the positive effect they have on the electoral competitiveness.

${ }^{15}$ For surveys of these economic effects of immigration, see Friedberg and Hunt (1995); Kerr and Kerr (2011); Leeson and Gochenour (2015); Zimmermann (1995). For studies looking at the increase in the demand for public education due to immigration, see Greer (1972); Everhart (1977); Butts (1978); Meyer et al. (1979); Ralph and Rubinson (1980); Bowles and Gintis (2011).

${ }^{16}$ Collier (2013) defines the social model as a component of institutions, rules, norms and organizations of a country.

${ }^{17}$ Migrants have four possibilities of behaving in their destination country. They can embrace the values and standards of the native-born populations - assimilation - or add their own values to them - cultural fusion. They could also live among themselves, isolated from the natives - cultural separatism. Finally, they could behave as settlers and try to impose their own culture.

Abdih, Y., R. Chami, J. Dagher, and P. Montiel (2012) "Remittances and institutions: Are remittances a curse?" World Development, 40 (4), pp. 657-666.

Acemoglu, D., S. Johnson, and J. A. Robinson (2005) "Institutions as a fundamental cause of long-run growth," Handbook of economic growth, 1, pp. 385-472.

Acemoglu, D. and J. A. Robinson (2013) Why Nations Fail: The Origins of Power, Prosperity and Poverty, New York: Crown, 1st edition, pp.529.

Ahmed, F. Z. (2013) "Remittances deteriorate governance," Review of Economics and Statistics, 95 (4), pp. $1166-1182$.

Alesina, A., R. Baqir, and W. Easterly (1999) "Public goods and ethnic divisions," The Quarterly Journal of Economics, 114 (4), pp. 1243-1284.

Alesina, A., E. Glaeser, and B. Sacerdote (2001) "Why doesn't the us have a european-style welfare system?" Working Paper 8524, National Bureau of Economic Research.

Anderson, J. E. (1979) "A theoretical foundation for the gravity equation," The American Economic Review, pp. 106-116. 
(2011) "The gravity model," Annual Review of Economics, 3 (1), pp. 133-160.

Anderson, J. E. and E. Van Wincoop (2003) "Gravity with gravitas: A solution to the border puzzle," The American Economic Review, 93 (1), pp. 170-192.

Ashby, N. J. (2010) "Freedom and international migration," Southern Economic Journal, 77 (1), pp. 49-62.

Bang, J. T. and A. Mitra (2011) "Gender bias and the female brain drain," Applied Economics Letters, 18 (9), pp. 829-833.

Barrett, A., M. Kahanec, K. F. Zimmermann, M. Kahanec, A. Myung-Hee Kim, and K. F. Zimmermann (2013a) "Pitfalls of immigrant inclusion into the european welfare state," International Journal of Manpower, 34 (1), pp. 39-55.

Barrett, A., M. Kahanec, K. F. Zimmermann, R. T. Riphahn, M. Sander, and C. Wunder (2013b) "The welfare use of immigrants and natives in germany: the case of turkish immigrants," international Journal of manpower, 34 (1), pp. 70-82.

Barrett, A. and Y. McCarthy (2008) "Immigrants and welfare programmes: exploring the interactions between immigrant characteristics, immigrant welfare dependence, and welfare policy," Oxford Review of Economic Policy, 24 (3), pp. 542-559.

Barry, B. (1974) "Review article:'exit, voice, and loyalty'," British Journal of Political Science, 4 (01), pp. 79-107.

Batista, C. and P. C. Vicente (2011) "Do migrants improve governance at home? evidence from a voting experiment," The World Bank Economic Review, 25 (1), pp. 77-104.

Baudassé, T. and R. Bazillier (2010) "Migration and Trade Union Rights," Swiss Journal of Economics and Statistics (SJES), 146 (IV), pp. 677-707.

- (2014) "Gender inequality and emigration: Push factor or selection process?" International Economics, 139, pp. 19-47.

Bazillier, R. and Y. Moullan (2010) Employment protection and migration: Laboratoire d'économie D’Orléans, DR LEO 2010-09.

_ (2012) "La protection de l'emploi influence-t-elle les flux migratoires destination des pays de l'ocde ?," Revue économique, 63 (3), pp. 491-499.

Beine, M., S. Bertoli, and J. Fernndez-Huertas Moraga (2016) "A practitioners? guide to gravity models of international migration," The World Economy, 39 (4), pp. 496-512.

Beine, M., F. Docquier, and Ç. Özden (2011) "Diasporas," Journal of Development Economics, 95 (1), pp. 30-41.

Beine, M., F. Docquier, and M. Schiff (2013) "International migration, transfer of norms and home country fertility," Canadian Journal of Economics/Revue canadienne d'conomique, 46 (4), pp. 1406-1430.

Beine, M. and C. Parsons (2015) "Climatic factors as determinants of international migration," The Scandinavian Journal of Economics, 117 (2), pp. 723-767.

Beine, M. and K. Sekkat (2013) "Skilled migration and the transfer of institutional norms," IZA Journal of Migration, 2 (1), p. 9.

Berdiev, A. N., Y. Kim, and C.-P. Chang (2013) "Remittances and corruption," Economics Letters, 118 (1), pp. 182-185.

Bergh, A., I. Mirkina, T. Nilsson et al. (2015) "Pushed by poverty or by institutions? determinants of global migration flows," Technical report.

Bertocchi, G. and C. Strozzi (2008) "International migration and the role of institutions," Public choice, 137 (1-2), pp. 81-102.

Bertoli, S. and F. Marchetta (2015) "Bringing it all back home ? return migration and fertility choices," World Development, 65, pp. 27 - 40, Migration and Development.

Blanchflower, D. G. and H. Lawton (2009) The Impact of the Recent Expansion of the EU on the UK Labor Market: Springer.

Blattman, C. and E. Miguel (2010) "Civil war," Journal of Economic Literature, pp. 3-57.

Boeri, T. (2010) "Immigration to the land of redistribution," Economica, 77 (308), pp. 651-687.

Böheim, R. and K. Mayr (2005) "Immigration and public spending."

Borjas, G. J. (1987) "Self-selection and the earnings of immigrants," The American Economic Review, pp. 
$531-553$.

(1999) "Immigration and welfare magnets," Journal of labor economics, 17 (4), pp. 607-637.

(2014) Immigration economics: Cambridge: Harvard University Press.

(2015) "Immigration and globalization: A review essay," Journal of Economic Literature, 53 (4), pp. 961-974.

Borjas, G. J. and L. Hilton (1996) "Immigration and the welfare state: Immigrant participation in meanstested entitlement programs," The Quarterly journal of economics, 111 (2), pp. 575-604.

Borjas, G. J. and S. J. Trejo (1993) "National origin and immigrant welfare recipiency," Journal of public economics, 50 (3), pp. 325-344.

Bowles, S. and H. Gintis (2011) Schooling in Capitalist America: Educational Reform and the Contradictions of Economic Life: Haymarket Books.

Brücker, H., S. Capuano, and A. Marfouk (2013) "Education, gender and international migration: insights from a panel-dataset 1980-2010," Retrieved March, 20, p. 2014.

Brücker, H., G. S. Epstein, B. McCormick, G. Saint-Paul, A. Venturini, and K. F. Zimmermann (2002) "Managing migration in the european welfare state," Immigration Policy and the Welfare System, Oxford University Press, Oxford, pp. 1-168.

Butts, R. F. (1978) Public education in the United States: From revolution to reform: Holt, Rinehart and Winston New York.

Chauvet, L. and M. Mercier (2014) "Do return migrants transfer political norms to their origin country? evidence from mali," Journal of Comparative Economics, 42 (3), pp. 630-651.

Cheong, P. H., R. Edwards, H. Goulbourne, and J. Solomos (2007) "Immigration, social cohesion and social capital: A critical review," Critical social policy, 27 (1), pp. 24-49.

Chukwu-Emeka, C. (2011) Reinforcing the Contribution of African Diasporas to Development, Chap. 9: World Bank.

Clark, J. R., R. Lawson, A. Nowrasteh, B. Powell, and R. Murphy (2015) "Does immigration impact institutions?" Public Choice, 163 (3), pp. 321-335.

Clemens, M. A., Ç. Özden, and H. Rapoport (2014) "Migration and development research is moving far beyond remittances," World Development, 64, pp. 121-124.

Collier, P. (2013) Exodus: How migration is changing our world: Oxford University Press.

Combes, J. L., C. Ebeke, and M. Maurel (2015) "The effect of remittances prior to an election," Applied Economics, 47 (38), pp. 4074-4089.

Constant, A. F. (2011) "Sizing it up: Labor migration lessons of the eu enlargement to 27," IZA Discussion Paper No. 6119.

Cooray, A. V. and F. Schneider (2014) "Does corruption promote emigration? an empirical examination," IZA Discussion Paper No. 8094.

Davis, J. (2011) "Decoupling migration effects from income effects on reproduction in central american migrant-sending households1," International Migration Review, 45 (2), pp. 325-347.

De Giorgi, G. and M. Pellizzari (2009) "Welfare migration in europe," Labour Economics, 16 (4), pp. 353-363.

Dimant, E., T. Krieger, and D. Meierrieks (2013a) "The effect of corruption on migration, 1985-2000," Applied Economics Letters, 20 (13), pp. 1270-1274.

Dimant, E., T. Krieger, and M. Redlin (2013b) "A crook is a crook... but is he still a crook abroad? on the effect of immigration on destination-country corruption," CESifo Working Paper Series No. 5032.

Docquier, F., O. Lohest, and A. Marfouk (2007) "Brain drain in developing countries," The World Bank Economic Review, 21 (2), pp. 193-218.

Docquier, F., A. Marfouk, S. Salomone, and K. Sekkat (2012) "Are skilled women more migratory than skilled men?" World development, 40 (2), pp. 251-265.

Docquier, F., E. Lodigiani, H. Rapoport, and M. Schiff (2016) "Emigration and democracy," Journal of Development Economics, 120, pp. 209 - 223.

Dumont, J.-C., J. P. Martin, and G. Spielvogel (2007) "Women on the move: The neglected gender dimension of the brain drain," IZA Discussion Papers 2920, Institute for the Study of Labor (IZA). 
Durkheim, E. (1982) The rules of sociological method and selected texts on sociology and its method: New York: The Free Press.

Durlauf, S. N. and M. Fafchamps (2004) "Social capital," NBER working paper series, p. 10485.

Dutta, N. and S. Roy (2011) "Do potential skilled emigrants care about political stability at home?" Review of Development Economics, 15 (3), pp. 442-457.

Everhart, R. B. (1977) "From universalism to usurpation: An essay on the antecedents to compulsory school attendance legislation," Review of Educational Research, 47 (3), pp. 499-530.

Fargues, P. (2006) The Demographic Benefit Of International Migration : Hypothesis And Application To The Middle Eastern And North African Contexts: The World Bank.

(2011) "International migration and the demographic transition: A two-way interaction," International Migration Review, 45 (3), pp. 588-614.

Fargues, P. and C. Fandrich (2012) "Migration after the arab spring," Migration Policy Centre Research Report.

Ferrant, G. and M. Tuccio (2015) "South?south migration and discrimination against women in social institutions: A two-way relationship," World Development, 72, pp. $240-254$.

Fidrmuc, J. and O. Doyle (2004) "Voice of the diaspora: An analysis of migrant voting behavior," CEPR Discussion Paper No. 4619.

Freeman, R. B. (2010) "Chapter 70 - labor regulations, unions, and social protection in developing countries: Market distortions or efficient institutions?" in D. Rodrik and M. Rosenzweig eds. Handbooks in Economics, 5 of Handbook of Development Economics: Elsevier, pp. $4657-4702$.

Friedberg, R. M. and J. Hunt (1995) "The impact of immigrants on host country wages, employment and growth," The Journal of Economic Perspectives, 9 (2), pp. 23-44.

Geis, W., S. Uebelmesser, and M. Werding (2013) "How do migrants choose their destination country? an analysis of institutional determinants," Review of International Economics, 21 (5), pp. 825-840.

Gibson, J. and D. McKenzie (2011) "Eight questions about brain drain," The Journal of Economic Perspectives, pp. 107-128.

Giulietti, C. and J. Wahba (2013) "Welfare migration," in C. Amelie and K. F. Zimmermann eds. International Handbook on the Economics of Migration, Cheltenham, UK, and Northampton, USA: Edward Elgar Publishing, Chap. 26, pp. 489-504.

Giulietti, C. (2014) "Is the minimum wage a pull factor for immigrants?" Industrial E Labor Relations Review, 67 (3), pp. 649-674.

Giulietti, C., M. Guzi, M. Kahanec, and K. F. Zimmermann (2013) "Unemployment benefits and immigration: evidence from the EU," International Journal of Manpower, 34 (1), pp. 24-38.

Greer, C. (1972) The Great School Legend: A Revisionist Interpretation of American Public Education:: New York: Basic Books.

Grogger, J. and G. H. Hanson (2011) "Income maximization and the selection and sorting of international migrants," Journal of Development Economics, 95 (1), pp. 42-57.

Gwartney, J. and R. Lawson (2013) "Economic freedom of the world: 2013 annual report," Technical report, Vancouver, BC: Fraser Institute.

Gwartney, J., R. Lawson, and S. Norton (2007) Economic freedom of the world 2008 annual report: The Fraser Institute.

Hansen, J. and M. Lofstrom (2003) "Immigrant assimilation and welfare participation do immigrants assimilate into or out of welfare?" Journal of Human Resources, 38 (1), pp. 74-98.

Hicks, J. (1932) The theory of wages: London: Macmillan.

Hirschman, A. O. (1970) Exit, voice, and loyalty: Responses to decline in firms, organizations, and states: Harvard university press. Cambridge, MA.

Hodgson, G. M. (1998) "The approach of institutional economics," Journal of economic literature, 36 (1), pp. 166-192. - (2006) "What are institutions?" Journal of Economic Issues, 40 (1), pp. pp. 1-25.

Kanaiaupuni, S. (2000) "Reframing the migration question: An analysis of men, women and gender in mexico," Social Forces, 78 (4), pp. 1311-1347. 
Karemera, D., V. I. Oguledo, and B. Davis (2000) "A gravity model analysis of international migration to north america," Applied Economics, 32 (13), pp. 1745-1755.

Kaufmann, D., A. Kraay, and M. Mastruzzi (2004) "Governance matters iii: Governance indicators for 1996, 1998, 2000, and 2002," The World Bank Economic Review, 18 (2), pp. 253-287.

_ (2007) "Governance matters vi: governance indicators for 1996-2006," World Bank policy research working paper (4280).

(2011) "The worldwide governance indicators: methodology and analytical issues," Hague Journal on the Rule of Law, 3 (02), pp. 220-246.

Kerr, S. P. and W. R. Kerr (2011) "Economic impacts of immigration: A survey," Finnish Economic Papers, 24 (1), pp. 1-32.

Lauby, J. and O. Stark (1988) "Individual migration as a family strategy: Young women in the philippines," Population Studies, 42 (3), pp. 437-486.

Lee, E. (1966) "A theory of migration," Demography, 3 (1), pp. 47-57.

Leeson, P. and Z. Gochenour (2015) "The economic effects of international labor mobility," in B. Powell ed. The Economics of Immigration. Market-Based Approaches.

Li, X. and J. McHale (2006) "Does brain drain lead to institutional gain? a cross country empirical investigation," Manuscript: Queen's University.

(2009) "Emigrants and institutions," University of Michigan, Ann Arbor, and National University of Ireland, Galway.

Licuanan, V., T. O. Mahmoud, and A. Steinmayr (2015) "The drivers of diaspora donations for development: Evidence from the philippines," World Development, 65, pp. 94 - 109, Migration and Development.

Lindstrom, D. P. and E. Muñoz-Franco (2005) "Migration and the diffusion of modern contraceptive knowledge and use in rural guatemala," Studies in Family Planning, 36 (4), pp. 277-288.

Lindstrom, D. P. and S. G. Saucedo (2002) "The short- and long-term effects of u.s. migration experience on mexican women's fertility," Social Forces, 80 (4), pp. 1341-1368.

Lodigiani, E. and S. Salomone (2015) "Migration-induced transfers of norms. the case of female political empowerment," University Ca'Foscari of Venice, Dept. of Economics Research Paper Series No, 19.

Mahmoud, T. O., H. Rapoport, A. Steinmayr, and C. Trebesch (2013) "The effect of labor migration on the diffusion of democracy: Evidence from a former soviet republic," CESifo Working Paper Series No. 4389.

Marchetta, F. (2012) "Return migration and the survival of entrepreneurial activities in egypt," World Development, 40 (10), pp. $1999-2013$.

McCormick, B. and J. Wahba (2001) "Overseas work experience, savings and enterpreneurship amongst return migrants to ldcs," Scottish Journal of Political Economy, 48 (2), pp. 164-178, cited By 76.

McFadden, D. (1974) "The measurement of urban travel demand," Journal of Public Economics, 3, pp. 303-328.

Melkumian, A. (2009) "A gravity model of legal migration into the united states," Journal of Economic Development and Business Policy, 2 (1), pp. 1-18.

Mercier, M. (2016) "The return of the prodigy son: Do return migrants make better leaders?" Journal of Development Economics, 122, pp. $76-91$.

Meyer, J. W., D. Tyack, J. Nagel, and A. Gordon (1979) "Public education as nation-building in america: Enrollments and bureaucratization in the american states, 1870-1930," American Journal of Sociology, pp. 591-613.

Morrison, A., M. Schiff, and M. Sjoblom (2007) The International Migration of Women, Washington, USA: The World Bank and Palgrave Macmillan.

Mountford, A. (1997) "Can a brain drain be good for growth in the source economy?" Journal of Development Economics, 53 (2), pp. 287 - 303.

Naghsh Nejad, M. and A. T. Young (2014) "Female brain drains and women's rights gaps: A gravity model analysis of bilateral migration flows," Available at SSRN 2191658.

(2015) "Want freedom, will travel: Emigrant self-selection according to institutional quality," Technical report, IZA Discussion Papers.

Narayan, P. K. and R. Smyth (2005) "Temporal causality and the dynamics of democracy, emigration and 
real income in fiji," International Review of Applied Economics, 19 (2), pp. 245-261.

North, D. C. (1984) "Transaction costs, institutions, and economic history," Journal of institutional and theoretical economics, 140 (1), pp. 7-17.

(1991) "Institutions," The Journal of Economic Perspectives, 5 (1), pp. pp. 97-112.

O’Mahony, A. (2013) "Political investment: remittances and elections," British Journal of Political Science, 43 (04), pp. 799-820.

Pedersen, P. J., M. Pytlikova, and N. Smith (2008) "Selection and network effects migration flows into oecd countries 1990-2000," European Economic Review, 52 (7), pp. 1160-1186.

Pedraza, S. (1991) "Women and migration: the social consequence of gender," Annual Review of Sociology, 17, pp. 303-325.

Pellizzari, M. (2013) "The use of welfare by migrants in italy," International Journal of Manpower, 34 (2), pp. $155-166$.

Pfutze, T. (2012) "Does migration promote democratization? evidence from the mexican transition," Journal of Comparative Economics, 40 (2), pp. 159-175.

de Pina-Cabral, J. (2011) "Afterword: what is an institution?" Social Anthropology, 19 (4), pp. 477-494.

Piper, N. (2005) "Gender and migration: Overview report," Policy Analysis and Research Programme. Geneva: Global Commission on International Migration.

Piracha, M. and F. Vadean (2010) "Return migration and occupational choice: Evidence from albania," World Development, 38 (8), pp. 1141 - 1155.

Poppo, L. and T. Zenger (2002) "Do formal contracts and relational governance function as substitutes or complements?" Strategic management journal, 23 (8), pp. 707-725.

Poprawe, M. (2015) "On the relationship between corruption and migration: empirical evidence from a gravity model of migration," Public Choice, 163 (3-4), pp. 337-354.

Putnam, R. D. (2007) "E pluribus unum: Diversity and community in the twenty-first century the 2006 johan skytte prize lecture," Scandinavian political studies, 30 (2), pp. 137-174.

Ralph, J. H. and R. Rubinson (1980) "Immigration and the expansion of schooling in the united states, 1890-1970," American Sociological Review, 45 (6), pp. 943-954.

Ravenstein, E. (1889) "The laws of migration," Journal of the Royal Statistical Society, LII, pp. $241-301$.

Ravenstein, E. G. (1885) "The laws of migration," Journal of the Statistical Society of London, 48 (2), pp. $167-235$.

Razin, A., E. Sadka, and P. Swagel (2002) "Tax burden and migration: a political economy theory and evidence," Journal of Public Economics, 85 (2), pp. 167 - 190.

Razin, A. and J. Wahba (2015) "Welfare magnet hypothesis, fiscal burden, and immigration skill selectivity," The Scandinavian Journal of Economics, 117 (2), pp. 369-402.

Rodrik, D. and A. Subramanian (2003) "The primacy of institutions," Finance and Development, 40 (2), pp. 31-34.

Rowlands, D. (1999) "Domestic governance and international migration," World Development, 27 (8), pp. $1477-1491$.

Roy, A. D. (1951) "Some thoughts on the distribution of earnings," Oxford economic papers, 3 (2), pp. $135-146$.

Searle, J. R. (2005) "What is an institution," Journal of institutional economics, 1 (1), pp. 1-22.

Solimano, A. (2005) Poverty, International Migration and Asylum, Chap. Development Cycles, Political Regimes and International Migration: Argentina in the Twentieth Century, pp. 251-275, London: Palgrave Macmillan UK.

Spilimbergo, A. (2009) "Foreign students and democracy," American Economic Review, 99 (1), pp. 528-43.

Stark, O. (1991) The Migration of Labour: Oxford University Press.

Stark, O., C. Helmenstein, and A. Prskawetz (1997) "A brain gain with a brain drain," Economics Letters, 55 (2), pp. $227-234$.

Tinbergen, J. (1962) "An analysis of world trade flows," Shaping the world economy, pp. 1-117.

Tyburski, M. D. (2012) "The resource curse reversed? remittances and corruption in mexico1," International Studies Quarterly, 56 (2), pp. 339-350. 
(2014) "Curse or cure? migrant remittances and corruption," The Journal of Politics, 76 (03), pp. $814-824$.

Vatn, A. (2006) "Institutions," International Society for Ecological Economics Internet Encyclopaedia of Ecological Economics.

Veblen, T. (2007) The theory of the leisure class: Oxford University Press.

Vogler, M. and R. Rotte (2000) "The effects of development on migration: Theoretical issues and new empirical evidence," Journal of Population Economics, 13 (3), pp. 485-508.

Williamson, O. E. (2000) "The new institutional economics: taking stock, looking ahead," Journal of economic literature, pp. 595-613.

Zimmermann, K. F. (1995) "Tackling the european migration problem," The Journal of Economic Perspectives, 9 (2), pp. 45-62. 